\title{
EXAMINING THE KENŌSIS OF THE CCAP BLANTYRE SYNOD IN POVERTY ALLEVIATION IN MALAWI $^{1}$
}

\author{
Q Jere (Mzuzu University) \& \\ DT Williams (University of Fort Hare)
}

\begin{abstract}
:
This article argues that the high level of poverty within the CCAP Blantyre Synod has been due to a lack of kenōsis within the church. The Synod is located in the southern part of Malawi which experiences the highest level of poverty in Malawi. If the kenōsis of Jesus were practised, it would lead to drastic change and enhance societal progress in the lives of the people. The CCAP Synod's inability to practise kenōsis in their daily social and economic life is reflected in the high level of poverty within the congregants and the entire Synod operating system.
\end{abstract}

Key Words: kenōsis, poverty alleviation, CCAP, Synod, Self-emptying, Humility.

${ }^{1}$ This article is based on chapter five of my Doctor of Theology thesis which was submitted in the Faculty of Social Science and Humanities at the University of Fort Hare in 2012 toward my D.Th graduation which took place on the 7th of May, 2013. The focus of this study was on the question of corruption and poverty within the Church and State, a comparative study covering Malawi, Zambia and Zimbabwe. This study was fully sponsored by the Malawi Government through the Malawi Government Scholarship scheme offer to the scholar to pursue the Doctoral degree study at the University of Fort Hare in 2008-2012. 


\section{INTRODUCTION}

This paper examines the application of the idea of kenōsis in the CCAP Blantyre Synod of the Presbyterian Church in Malawi. Kenōsis is seen in Jesus' life, providing a model of selfemptying and humility. He demonstrated this to humanity for the sake of bringing about complete and long lasting change in the lives of the people. Unless the church of God becomes kenotic, the gap between the poor and the rich will continue to follow the pattern of the secular state where economic segregation and diversity of opportunity tend to divide the people more. This paper therefore shows that lack of true kenōsis within the CCAP Blantyre Synod has hugely contributed to the alarming poverty within the ecclēsia.

\section{BRIEF HISTORY OF THE CCAP BLANTRYE SYNOD}

The Blantyre Mission was the second Presbyterian mission to be established in Nyasaland in 1876. It was named after Livingstone's birthplace in Scotland. The site for the mission was identified by Henry Henderson when he was still at Cape Maclear working with the Livingstonia Mission under the leadership of Young and Laws. Ross (1996:41) says that Henderson's main task was to find a site for the mission of the established Church of Scotland that was both suitable in itself and conformed to the specifications of the agreement between the two churches, that it should be close enough for each mission to be able to aid the other.

Selfridge (1976:30) says that with this in mind, Henderson made a trip round the lake on the steamship Ilala, as instructed by his committee, to find a site on the shores of the lake, but he could not find a place that he considered suita- 
Examining the KENOSIS of the CCAP of Blantyre Synod in poverty alleviation in Malawi

ble. He therefore returned to Cape Maclear, from where he considered the possibility of sitting the mission in the Shire Highlands which he had passed through on the journey up the Shire. Selfridge (1976:32) notes the following about Henderson.......

...leaving his friends at Cape Maclear he traveled south to the foothills of the mountain range and then climbed up the plateau. He took a course past the old site of the UMCA Mission and when he had gone a further thirty miles south, his interpreter took ill and was not able to travel again for three weeks. This gave Henderson time to thoroughly explore the surrounding country and because he found it well watered and the soil good, judging from the gardens of the local people, he decided to suggest that the location of the

Mission headquarters should be in that vicinity

On his mission to identify the site for the Established Church of Scotland, the Livingstonia Mission rented Henderson an interpreter called Bokwito who was important in communicating with the local chiefs in the area. After leaving Cape Maclear, Henderson and Bokwito travelled through Machinga and Zomba until they reached Mount Nyambadwe in the land of Chief Kapeni (Phiri 2004:134). This location and vicinity was the one chosen for the new mission station around Ndilande Mountain in Chief Kapeni's area along the Shire Highlands (Laws 1934:8). Regarding the way the Blantyre site was identified, some argue that it was only after the arrival of the first party in the following year (1876) that a location in the vicinity of Ndilande Mountain was chosen (Du Plessis 1929:301). However, the researcher supports the notion shared by Selfridge (1976:31) who argues that Henderson was alone with his interpreter when he visited Chief 
Kapeni's area for the first time. It was only after the site ${ }^{2}$ was identified that he went down the Zambezi River to meet the second missionary party consisting of the Free Church of Scotland and the Established Church of Scotland all under the leadership of James Stewart ${ }^{3}$. Phiri (2004:136) points out that it was on 23 October 1876 that the Blantyre mission party led by Henderson arrived in Chief Kapeni's area which they called Blantyre. Selfridge (1976:32) says that Chief Kapeni gave these missionaries a place because he wanted them nearby as he feared the Makololo and Maseko Ngoni west of the Shire River.

\subsection{Early years of settlement 1876-1881}

According to Du Plessis (1929:301-302), the Blantyre Mission did not commence on a positive note due to repeated attacks of fever, and the inexperience of the missionaries who could not understand the local people. Phiri (2004:135) says that while Henderson had succeeded in finding a suitable site for the Blantyre Mission, Dr. Macrae in Scotland had failed to find an ordained minister to go and start work in the Shire Highlands. Instead laymen came because they were promised salaries. Some of these were Christians only in a very technical sense and had no calling to work as missionaries. This is likely the reason why the Blantyre Mission

2 Thus Selfridge adds that after making this decision, he proceeded down the river to meet the new party which had been sent out by the Church of Scotland. On the 2nd of September 1876 he met the party on the banks of the Zambezi. Accompanying them was also a second party of missionaries for the Livingstonia Mission.

3 James Stewart was the founding head of the Lovedale Mission Station located in the small town of Alice in the Eastern Cape of South Africa. This was the main resting place for many missionaries on a journey into the interior of Africa. 
Examining the KENOSIS of the CCAP of Blantyre Synod in poverty alleviation in Malawi

artisans $^{4}$ who were not religious enough flogged and executed native people without proper legal procedures being followed (Weller et al 1984:45). The missionaries' problem was quite intense due to their inexperience with little knowledge of how to carry out missionary work since they came for their own income generating activity. Their involvement in the unholy activities shows the type of men they were and how much of a problem they were to the functioning of mission work in the early part of the Blantyre mission (Weller et al 1984:45).

\subsection{Dr. Laws temporarily in charge of the Blantyre mission 1877-78}

By April 1877, Henderson felt that his work of finding a site for the mission and seeing it established had ended, so he prepared to leave for Scotland. Selfridge (1976:34) points out that before leaving he had a strong conviction that the time had come for an ordained minister to take control of the mission station. Since no minister seemed to be available from Scotland, Henderson wrote to ask Laws to come and take charge of the mission until the arrival of Duff MacDonald (Ross 1996:44). Having agreed to Henderson's pleas, Laws and Stewart agreed to jointly take care of the Blantyre Mission until a leader was identified. In this regard, Selfridge (1976:34) notes that both Laws and Stewart took periods away from Livingstonia to supervise the work at Blantyre mission until July 1878 when MacDonald arrived to take charge.

4 These Artisans who flogged Africans, some to death, were John Buchanan, John Walker and George Fenwick (See DD Phiri, History of Malawi p.136. 


\subsection{The Blantyre Mission scandal}

By 1978, MacDonald took charge of the Blantyre Mission. Phiri (2004:136) notes that though MacDonald arrived at the Blantyre Mission, there were some key challenges in terms of administering the station. According to Ross (1996:64), the outstanding and disappointing activity was the poor behaviour and actions of some of the first team of missionaries who were involved in the most unholy activities against the locals. This was called the Blantyre scandal because the missionaries who came to preach God's word were involved in the mistreating of the same people to whom they came to minister; it was hardly a good imitation of the humility of Christ. He adds that due to this behavior, the Foreign Office instituted a commission led by Dr. Rankin and Mr. Pringle to investigate the reports that came from Nyasaland about the behaviour of these missionaries. This misconduct led to MacDonald's resignation and the dismissal of the artisans, while at the same time, it also led to the appointment of new church leaders to take over the Blantyre Mission work.

\section{CLEMENT SCOTT 1881-1898}

Clement Scott took over the leadership of the Blantyre Mission after the first five scandalous years the mission had gone through under the leadership of Henderson. Scott was chosen by the Church of Scotland to become the next overseer as he was in full agreement with the policies which had been settled after the enquiry and also with the respectful attitude toward African customs which the Commission's members adopted (Weller et al 1984:45). In October 1881, the year in which the Livingstonia Mission moved its headquarters from Cape Maclear to Bandawe, Scott and his wife arrived from Scotland to assume responsibility for the Blantyre Mission (Selfridge 1976:44). 
Examining the KENOSIS of the CCAP of Blantyre Synod in poverty alleviation in Malawi

\subsection{Scott's outstanding activities}

The success of Clement Scott in his missionary work in then Nyasaland is seen in the following major activities he successfully accomplished. According to Baur (1994:209) Clement Scott managed to save the mission by giving it a new direction similar to that of CCAP Livingstonia mission. $\mathrm{He}$ adds that Scott came to evangelistic work by which he believed in spreading the gospel of Christ in an African culture $^{5}$. In addition, Scott's main goal was to promote education which given in an African form. Outstandingly, Scott empowered Africans to develop Christianity for local people and help them become members of the true universal Church. Also he firmly believed that Africans were part of the same humanity and that they would contribute to the Christian Church as well as benefit from it like the rest of advanced societies globally (Pachai 1972:206).

\subsection{Major achievements of Scott at Blantyre Mission}

As the leader of the Blantyre Mission, Scott's key achievement was the construction of the Cathedral. Phiri (2004:138) says that Scott started building the main church in 1888 with the full cooperation of African workers. He says that within three years, and on $10^{\text {th }}$ May 1891, the church building, named St Michaels and All Angels, was officially dedicated by Scott himself. In addition to the construction of St Michaels and All Angels, some key mission stations were opened in the southern part of Nyasaland in his tenure, including Domasi, Chiradzulu and Mulanje (Ross 1996:82). As well as opening up stations, Scott promoted training of the local people, some of whom he sent to Scotland; one was Mungo Chisuse who went to Scotland to learn printing (Phiri

5 Also See Andrew Ross, Blantyre Mission, p.63. 
2004:137). In November 1894, Scott ordained some Africans as deacons who included Joseph Bismarck, Henry Kambwiri Matecheta ${ }^{6}$, Mungo Murry Chisuse and John Gray Kufa (Phiri 2004:139).

\section{CHURCH AT CROSSROAD AND THREATS}

The British and the Portuguese were the major players in southern African in the partitioning of Africa. The Portuguese and the British had unresolved issues over the Shire Highlands in the Nyasa region. The Portuguese wanted to take over the entire Shire Highlands whereas by 1885 British missionaries had stayed in the area for ten years. During this time, the future and destiny of the mission was at a crossroads, because the Portuguese claimed that its colony of Portuguese East Africa stretched to the south eastern parts of Lake Nyasa and the Shire Highlands (Kalinga 1998:526). At this time, the two Scottish mission stations ${ }^{7}$, Anglicans (UMCA) and the Lakes Company were fully established in Nyasaland.

\subsection{The Portuguese threats: $\mathbf{1 8 8 5 - 1 8 9 0}$}

The first threat to missionary work in Nyasaland was the Portuguese intention to take over the Shire Highlands. Phiri (2004:203) states that the Portuguese Governor at Quelimane made preparations to occupy Blantyre, something that alarmed the Scottish missionaries who then put

6 In 1911, Henry Kambwiri together with Stephen Kundache were officially ordained as clergy of the Blantyre mission (See Andrew Ross, Blantyre Mission, p.140).

7 These were the Livingstonia Mission who came in 1875 and this time had moved to Bandawe and crossed into the Northern and Eastern Rhodesia. The other was the Blantyre mission which came in 1876 and was stationed in the entire southern part of Nyasaland. 
Examining the KENOSIS of the CCAP of Blantyre Synod in poverty alleviation in Malawi

pressure on their government to resist Portugal's advance inland. The Scots placed much pressure because if the Portuguese succeeded in taking over the area (Southern Nyasaland and Shire Highlands), all the work by the Presbyterian missions and traders would come to an end (Selfridge 1976:51); and, instead, the Portuguese could have enforced their Catholicism in the area. Again, this political wrangling was hardly a reflection of Christ!

\subsubsection{Southern Nyasa into Portuguese control}

In 1886, the Portuguese Consul, Cardoso, visited the Shire Highlands and the Makanjila area where he bribed some chiefs to accept Portuguese dominion (Phiri 2004:205). In 1887, the Lisbon Government published maps showing Nyasaland as part of the Portuguese empire. In July 1888, the King of Portugal authorized the opening of a Portuguese station in southern Nyasaland to act as a centre from which Portugal could enlarge her influence in that region (Axelson 1972:252). At the same time, the British Prime Minister Lord Salisbury appointed Harry Johnston as the British consul in Mozambique who was sent to Lisbon (Phiri 2004:2006). Ross (1996:106) states that Johnston was instructed to negotiate a preliminary agreement on the basis of which a treaty could be concluded with Portugal clearing up the difficulties with her in Zambezia. However, Johnston's visit to Portugal produced a draft which handed over the Shire Highlands to the Portuguese (Weller et al 1984:46).

\subsubsection{Harry Johnson's push to hand southern Nyasaland to Portugal}

By 1888, Johnson the British consul and BSAC representative had almost given in to the Portuguese pressure to take the entire Nyasa region, while at the same time, the area had British activities through the Presbyterian missionary 
work and the African Lakes Company. During this time, Johnson's main goal was to build an empire and not to safeguard Blantyre. Hanna (1956:136) points out that Johnson's role was to safeguard the rights of the cape colonists, to expand northward beyond the Zambezi as far as Tanganyika and to keep the Portuguese out of Blantyre. Hanna adds that in his letter to Salisbury (1889), Johnston did not respond to the sentiments and concerns of British missionaries already in the Nyasa region because he argued that the missionaries' concerns in the Shire District were not the only element for consideration in an assignment with Portugal. Johnston added that there are interests and expectations of various British subjects who were awaiting concessions from the Portuguese government for opening up of mining and agriculture in the Sofala region.

\subsection{The Scottish missionary and eleven thousand signatures}

Ross (1996:107) says that word of Johnston's terms of agreement with Portugal soon reached the missionaries where Scott could not believe the report to be serious and wrote:

..rumour from home reach us of a division of territory between Portugal and Britain in which the Shire is the boundary line. This is disastrous if it is true: it is indeed keeping the shell and giving the Portuguese the kernel. We must hold fast to this stronghold and gateway of African civilization whatever comes and in this face of what Lord Salisbury and the home authorities know of the Shire Highlands we feel persuaded enough to say of the possibility of its eventually becoming Portuguese that we don't believe it. (DC Scott in

Ross 1996:107) 
Examining the KENOSIS of the CCAP of Blantyre Synod in poverty alleviation in Malawi

Selfridge (1976:52) says that Salisbury himself was not happy about handing over the southern part of Nyasaland and was glad to have the Scots strengthen his hand in the negotiations with the Portuguese and that he gave Johnston the task to sell the contents of the draft to missionaries in Scotland. Weller et al (1984:47) state that as Johnston argued the case (to have Blantyre given to the Portuguese), the leaders of the Church of Scotland in their campaign in Scotland produced eleven thousand signatures demanding the re-negotiation of the terms in such a way as to exclude the Portuguese from the southern lakeshores and Shire Highlands. With this evidence of support behind him, Lord Salisbury in 1890 issued the ultimatum which led to the definition of the present Malawi-Mozambique boundary. Hanna (1956:183) notes that on 14 May 1891, the Foreign Office issued a formal notification which was published in the London Gazette that under and by virtue of Agreements with the native chiefs and by other lawful means, the territories in Africa hereinafter referred to as the Nyasaland Districts, were under the Protection of Her Majesty the Queen. Thus in 1891, the entire Nyasaland became a British protectorate.

What is perhaps striking in the history of the area is that neither the attitudes of missionaries, especially the artisans, nor that of political authorities, reflects an attitude of the kenōsis that was put forward by Jesus as an example for his followers. It is hardly surprising that the Christian church that emerged out of that situation then failed to live up to that example. 


\section{UNDERSTANDING KENŌSIS}

According to Hayden (2009:1) the ancient Greek word kenōsis ${ }^{8}$ means "emptying" or the action of emptying. It derives from kenōs meaning "empty or purged" and from the Greek verb kenóo meaning "to empty out". Williams (2007:vii) says that the Philippians hymn (Phil 2:5f) in which this word is prominent, is set in a passage in which Paul is encouraging his readers to live the sort of life that is appropriate for their profession, which means one in obedience to and in imitation of their Lord.

In practising kenōsis, Jesus self-emptied, self-limited and humiliated himself for the sake of saving lost humanity. Blanchard (1993:60) says that in his kenōsis, Jesus Christ, the eternal Son of God, voluntarily gave up the independent use of His divine attributes in order to fulfill his purpose in coming into the world. Williams (2007:231) adds that Jesus in his kenōsis, went through all that agony not only for us, but also that he might gain the fullness, the completion, or wholeness of his body which led finally to glorification and exaltation.

\subsection{Kenoticism in Philippians}

According to Strong (2001:2073), the word "mind" comes from the Greek verb, "phroneō" which has the connotation of thinking, holding an opinion, and setting one's mind on, and having a certain attitude while the word "form" comes from the Greek noun, "morphe" which means nature or character

8 "Have this mind among yourselves, which is yours in Christ Jesus, who, though he was in the form of God, did not count equality8 with God a thing to be grasped, but emptied himself, talking the form of a servant, being born in the likeness of men. And being found in human form he humbled himself and became obedient unto death, even death on a cross." (Phil 2:5-8 RSV) 
Examining the KENOSIS of the CCAP of Blantyre Synod in poverty alleviation in Malawi

(Strong 2001:2025). In addition, the word "grasping", which comes from the Greek noun "harpagmos", means "to hold on to something" (Strong 2001:1995), while the word "equal/equality comes from the Greek noun "isotēs", which means, "same", "much like" (Strong 2001:2025). The preexistent Christ who was in the form of God counted not his being in equality with God a thing to be grasped. Christ could have existed and have appeared as God in a manner equal to God, a right which was due to him, but did not. The section below exposes the three major statements in understanding the Philippian song.

\subsubsection{Imitating the mind of Christ}

This Philippians song in verses 5 and 6 says that Christians need to have the mind of Christ or emulate the attitude of Jesus Christ who though he was God (in nature) did not refrain from bringing himself to the level of human beings; he brought himself so low and therefore limited or reduced himself so as to achieve God's salvation plan for humanity. Williams (2009:83) says that incarnation did not involve a change in his essence, but that during the period of earthly incarnation, the second person of the holy Trinity limited ${ }^{9}$ himself. Augustine once said that God gives where he can find empty hands (Foster 2000:199). In his incarnation, Jesus was not manifesting the attributes of his divinity as he could affirm that, the Father is greater than him (John14:28).

9 Perhaps we tend to resist the idea of God's self-limitation not just out of respect for God, but also because it implies that in imitation of him we should also limit ourselves. 


\subsubsection{Self-emptying of Christ}

The self-emptying of Christ in the Philippians' song did not include the relinquishing of his divinity (Williams 2007:224). Ellis (2009:2) says that from a kenotic angle, Jesus laid aside his status and suffered a humiliating death rather than lead his followers into violent resistance. In doing so, he became the supreme model for kenōsis and paradoxically, his influence long-outlasted those who executed him.

Gavrilyuk (2005:225) in his explanation of self emptying says that the father as well emptied himself in begetting the Son as he gave himself entirely to the Son. On the same the Father comes out of himself and found fulfillment in and identified himself with the being of the Son. He adds that the Father emptied himself into the Son without in any way being limited by him because the Son shares in the same infinite and unfathomable divine nature. The Son on his part empties himself by submitting to be begotten from the Father and by being obedient to the Father.

According to Richard (1982:40), self-emptying is neither self-effacement nor servility, but letting go for the sake of others. This is basically a situation where Christ abandoned his other functions as God and reduced himself to the level where he could properly execute his divine assignment of saving the lost humanity. The kenōsis of Jesus existed in Christ taking the form of a servant and being made in the likeness of men through his incarnation.

\subsubsection{Humility}

Thirdly is that humility remains vital in the exposition of the Phillipians' song in that in as much as Christ is God, he brought himself low for the sake of saving the lost humanity. A brief look into verse 7 according to Strong (2001:2066) 
Examining the KENOSIS of the CCAP of Blantyre Synod in poverty alleviation in Malawi

reveals that the word "humility or humble" comes from the Greek verb, "tapeinō" which means "to lower oneself" or "brought low" while the Greek noun "tapeinōsis" has the connotation of "humiliation", made low, humbleness and low estate. Humility according to Ravenhill (1961:148) is essential and is clearly seen through certain unique and unusual actions where even though Christ had all the necessary means and know how to act as God, he reduced himself, made himself low to be equal with humanity which he created (Jn 1:1). As in the Philippian hymn, James 4:10 indicates that exaltation and upliftment is achieved after someone humbles himself. So, while Christ humbled himself through the suffering and even death on the cross, he gained and restored everything back to God.

\subsection{The kenotic thought}

The main issue after the Arian controversy was how to reconcile the two natures (humanity and divinity of Christ), something which neither Nicaea nor Chalcedon solved. While the affirmation of Christ's full deity was essential for salvation, it was hard to see how full deity could incarnate. McClain (1967:1) states that having successfully repelled the Arian assault, the attention of the church logically shifted to another problem and that was how to reconcile proper Deity and true humanity in the Person of the historic Saviour, Jesus Christ. He describes how that discussion ran the gamut of various conceivable opinions where men, according to their particular bias, became Apollinarians, Nestorians, Eutychians, Monophysites, Monothelites and Adoptionists. However, Blanchard (1993:56) says that these heresies were outlawed by the Synod of Constantinople in 448 AD and the Council of Chalcedon, in 451 AD. According to McClain (1967:11), it was at Chalcedon (451) that the church declared that in the Saviour there are two natures, 
one divine and the other human which were described as perfectly and organically united in one Person, yet they remain distinct, each retaining its complete integrity ${ }^{10}$. But while affirming these, it was hard to understand how it could be possible.

Out of the many attempts that were made to solve and reconcile the divinity and humanity of Christ in relation to incarnation, the breakthrough came from the application of Philippians 2 which applied kenōsis as a theory and kenotic theology as a theological framework and the operating system. Kenōsis was the only better way of understanding and making sense of the technical aspects of the humanity and divinity of Christ. Essentially, divinity was seen to be incarnate only if it self-limited in kenōsis.

According to McClain (1967:1), it was the words of Philippians 2 that gave rise to the nineteenth century "Kenotic Theory" which stated that Christ laid aside, not his divine nature but the privileges that had been eternally His, co-equal with the Father and the Spirit, in that he was born God man through incarnation. It was at that time that kenōsis became a hotly debatable issue. Packer (in Blanchard 1993:58) states that in England kenōsis theory was first broached by Bishop Gore in 1880 to explain why our Lord was ignorant of what the nineteenth century higher critics thought they knew about the errors of the Old Testament. This could not be an inherent limitation, but a self-restriction if the error of Arianism was to be avoided. Since then the concept has generated a branch of theology called, "Kenotic Theology" (Grudem 1994:555-570). Self-limitation, in imitation of Christ, has

10 The Chalcedon's declaration did not show and explain how these two natures in Christ were reconciled together and didn't explain incarnation. 
Examining the KENOSIS of the CCAP of Blantyre Synod in poverty alleviation in Malawi

been seen to have many applications in Christian life and practice. Indeed, if it is fundamental to the incarnation, it is fundamental to Christianity.

\section{KENŌSIS OF THE CCAP BLANTYRE SYNOD}

The Philippian epistle argues that the Christian life should be in imitation of Jesus' example, so should then be one of kenōsis. The ongoing challenge for Christians and specifically those in the CCAP Blantyre Synod is how to transfer that into practice. There are two general principles that can be applied, as they reflect the way in which Jesus selflimited. Firstly the Philippian text indicates that Jesus limited himself to be a servant (Phil 2:7). He was not doing this for his own sake, but for the benefit of others. Then service implies work, and indeed the need is for Malawians to work if they are to escape poverty ${ }^{11}$. This does not mean that they are lazy, indeed Malawians are a people who are most industrious; there is a real contrast with South Africa, which does not in general display the same quality of industriousness.

The writer of the Philippian hymn, in describing Jesus as a "servant", explains that he became in the likeness of people. The allusion must be to the creation story, specifically to the creation of people in the image and likeness of God. It is in reflecting that that Christians do as God intended. What is then significant is that the primal couple was sent to care for the garden. They were involved in agriculture, which is certainly a close reflection of the original creation. It might just be observed here that modern people often feel that agricul-

11 Hard work is one of the three major pillars set by Malawi's current President, His Excellency Prof Peter Muthalika where he orders Malawians to develop the culture of hard work so as to get rid of poverty and help in the nation's development. 
ture is demeaning, and they do not want to humble themselves in that way; they prefer "white collar" occupations. However, the Philippian hymn speaks of Jesus as humbling himself, and it should not be felt that agriculture is too demeaning for Christians.

It must therefore be seen as an appropriate manifestation of the imitation of the kenōsis of Jesus for Malawians of Blantyre Synod to labour for the sake of others, and specifically in agriculture. It is to be hoped that just as the kenōsis of Jesus was ultimately succeeded by glory (Phil 2:10), so there will be ultimate benefit to Blantyre synod, to Malawi, and indeed to the world from their practice.

The CCAP Blantyre Synod is housed in Malawi's commercial capital of Blantyre named in honour of David Livingstone's birth town of Blantyre in Scotland. Since precolonialism, Blantyre has been the key business center for Malawi. The CCAP Blantyre Synod in poverty alleviation involves the synod's kenotic action through the creation of the Presbyteries' Poverty Alleviation Committee which would formulate action plan to end poverty within the presbyteries. At the same time, Synod kenotic action in poverty alleviation would begin with the poor themselves who would be guided toward their liberation path from poverty. The synod would reflect Christ's kenōsis whereby Jesus indentified the key need of humanity hence he limited himself for their salvation to be possible. In the same way, the Synod would indentify inborn expertise and utilized them from within the poor in their economic liberation process.

Not all presbyteries within CCAP Blantyre Synod would have similar poverty alleviation initiatives because it would depend on the poverty alleviation strength of the specific Christians and the type of natural resource available in their 
Examining the KENOSIS of the CCAP of Blantyre Synod in poverty alleviation in Malawi

respective presbyteries for economic empowerment. Therefore, through the Presbyteries' Poverty Alleviation Action, the CCAP Blantyre Synod would organize the presbyteries according to their economic strength for economic empowerment.

\subsection{Fruits and Veg Synod initiative}

Fruits and Veg initiatives would be the major kenotic step that the Synod would take toward helping to empower the people within the presbyteries' of Mwanza, Thyolo, Mulanje, Ntcheu and Chiradzulu. Just like Christ self-emptied and humbled himself, going to the cross not for himself but for the benefit of others, the Synod would do likewise. It would first identify and strategise on how the presbyteries within this jurisdiction could get empowered and economically liberated. This is how the fruits and veg production within this jurisdiction could help in the poverty alleviation of the people.

These five districts in the southern region of Malawi produce a variety of fruits and vegetables for the commercial city of Blantyre. Specifically, the CCAP Blantyre Synod presbyteries of Mwanza, Thyolo and Mulanje produce large scale assorted fruits which include bananas, pineapples, avocado pears, mangoes and oranges which would lead to the production of assorted fruit juices for market. This is because in these presbyteries, the peoples' main source of income is fruits farming in which Christians sell the raw fruits to the main market in the commercial cities of Blantyre and Zomba. Modification of this venture by the Blantyre Synod to install machines for the production of assorted juices would bring about change in the economic lives of the people in these presbyteries which at the same time would enhance 
and encourage many synod Christians to venture in fruit farming.

For Ntcheu and Chiradzulu presbyteries, the main point of contact for the people's poverty alleviation would be vegetable gardening, since these two districts are the chief suppliers of tomatoes, onions, cabbage and potatoes to the markets of both Blantyre and Lilongwe. In this regard, the CCAP Blantyre Synod, through the Presbytery Poverty Alleviation Action, would initiate the establishment of fresh fruits and vegetables shops where Christians would sell their produce at a competitive price. This would mean that the CCAP Blantyre Synod would initiate distribution points for the farmers of these vegetables. The support of the entire synod in this initiative would go a long way in boosting the Christian vegetable farmers who would eventually expand their trade and materially become independent suppliers and eventually get economically empowered.

\subsection{Staple food production}

The large scale production of Malawi's staple food crops of maize and rice would be one such good poverty alleviation action for the Christians in the presbyteries of Migowi, Thutchira and Domasi. The people in these three synod presbyteries produce and supply staple food crops which have sustained generations in this CCAP Blantyre Synod. Like the heart of Christ's kenōsis was self-giving, the presbyteries of Migowi, Thuchira and Domasi would give themselves out and produce more not for themselves but for the betterment of others through the production of large scale maize and rice which would be sold to grain and milling companies. Now the CCAP Blantyre Synod would, through the presbyteries, help Christian farmers create cooperatives or farming groups with the purpose of having farmers jointly 
Examining the KENOSIS of the CCAP of Blantyre Synod in poverty alleviation in Malawi

supply maize and other grain crops to big companies for more profit. This is bearing in mind that Migowi, Thutchira and Domasi produce sizeable maize and rice to feed the southern region of Malawi ${ }^{12}$.

\subsection{Presbyteries commercial farming}

Lack of Presbyterian kenōsis has led to poverty in the Chingale, Chikwawa, Shire south and Livilizi presbyteries in that since the people in the area have been doing cotton farming since independence, still their lives have remained the same with no meaningful progress. To effectively lift the Synod for effective economic empowerment of the people, the CCAP Synod mother body would self empty itself by letting the presbyteries get more authority in economic empowerment process. The economic empowerment and poverty alleviation of Christians in the Livilizi, Chingale, Chikwawa and Shire-South presbyteries would not take place outside the commercial activity of cotton farming (Twaibu ${ }^{13}$ 2007).

By and large, these four areas produce cotton for Malawi and some of the people involved in the production are Christians of the CCAP Blantyre Synod. To enhance the effectiveness of the production of cotton and marketing, the CCAP Blantyre Synod would organize Christian cotton farmers into Cotton Presbyterian clubs and link them with the Mapeto David Whitehead company and other big cotton buyers internationally. This would stimulate Christians' involvement in the respective zones to venture into this type of

12 The southern region houses half of the population of Malawi which entails that there is need for the increase in supply of maize for the production of flour which is the nation's staple food.

13 Mrs. R.W. Taibu is currently the coordinator for Health programmes of the Blantyre Synod. 
activity, and the CCAP Blantyre Synod involvement would create a positive step in ensuring that Christians directly benefit from the industry hence alleviating their own poverty in turn.

\subsection{Small scale business and fish farming}

Finally, the three remaining CCAP Blantyre Synod presbyteries of Mangochi, Zomba Rural and Chiuta have fish business as the dominant source of income for the people in the area (Mokiwa ${ }^{14}$ 19/5/11). Many in these presbyteries are basically business oriented people and fishing as a business is what defines their existence and it is passed on from one generation to the other. Tapping from fish farming business, the CCAP Blantyre Synod would organize Christians into groups which would be linked to the nation's departmental stores, hotels, motels and institutions of learning to provide them with fish as one of the most needed food items. Since many of such institutions are within the city of Blantyre and Zomba in the southern region, the CCAP Blantyre Synod would create this business venture as a way of enhancing productivity and also helping Christians acquire profit from of their business and in turn promote their livelihood at household level.

In addition, the CCAP Blantyre Synod presbyteries of Blantyre city, Blantyre north and Zomba city are some of the major presbyteries where majority of Christians' main income generating venture are white collar jobs and small scale businesses (Mangisa ${ }^{15}$ 25/2/07). In this regard, the CCAP

14 Rev. Mokiwa is the sitting parish minister at Lunchenza of the CCAP Blantyre Synod.

${ }^{15}$ Rev. Raynold Mangisa was in 2007 the resident clergy for St Michael and All Angels of the Blantyre Synod. He is currently (2016) the clergy at Zomba CCAP Church. 
Examining the KENOSIS of the CCAP of Blantyre Synod in poverty alleviation in Malawi

Blantyre Synod would provide a platform and help their Christians get financial capital in a form of soft loans from banks that support small scale businesses. The synod through the Presbyterian Poverty Alleviation Action would encourage those in white collar positions in Blantyre and Zomba to patronize and support their fellow Christians involved in small scale businesses by buying from them in what would be called supporting the home industry initiative.

Having looked into the respective presbyteries' poverty alleviation action in relation to how these initiatives would enhance poverty alleviation and economic development at presbyteries' and household level, it is important to bear in mind that the success of any poverty alleviation strategy depends on the decisions of both the poor and the initiators of such poverty alleviation activities. For the CCAP Blantyre Synod presbyteries', this would be the kenotic action of the synod itself where in its humility and self-limitation it would self-empty itself and directly take charge in empowering the people. In this regard, the application of kenotic principles would be in such a way that CCAP Blantyre Synod would economically empower Christians in their respective synod presbyteries. The CCAP Blantyre Synod would act out of love for the poor in their midst and like Christ would, be willing to do something about it. Economic action of Christ through incarnation was the manifestation of love for the lost humanity (Williams 2007:172), the same love motivates the church and Christians to take action in helping the poor get out of poverty.

\section{CONCLUSION}

In this paper we have examined the history of the CCAP Blantyre Synod in relation to what could efficiently work better to properly address the question of poverty in the Synod. 
It was noted that much in its history could hardly be said to reflect the example of humility shown by Christ in his incarnation. At the same time the Synod played a role in safeguarding the southern territories from the Portuguese, but again the attitude of conflict hardly reflects Christ. Hence whereas kenotic principles have been used to help to address the poverty challenge, it is hardly surprising that these have not been adhered to adequately. While the industry of Malawians does reflect the nature of the one who came as a servant, and that it is generally in agriculture reflects the creation of the first couple in the image of God, the imitation of Christ needs to be more consistent. If this were the case, there would be an expectation of following the path of Christ further into glorification.

\section{REFERENCES}

Axelson, E. 1972. Portugal's attitude to Nyasaland during the period of the partition of Africa, in Pachai (ed) the Early History of Malawi. Longman: London (252-262).

Baur, J. 1994. 2000 Years of Christianity in Africa. Pauline publication: Nairobi.

Blanchard, J 1993. The Humanity of Christ. Reformation \& Revival. A Quarterly Journal for Church Leadership. Volume 2, Number 2 • Spring (55-66).

Du Plessis, J. 1929. The Evangelization of Pagan Africa-a History of Christian Mission to the pagan Tribes of Central Africa. J.C Juta: Cape Town.

Foster, R J 2000. Prayer: finding the heart true home. Hodder \& Stoughton: London.

Gavrilyuk, P. L., 2005. The kenotic theology of Sergius Bulgakov. Scottish Journal of Theology, 58 (3), 251-269.

Grudem, W.A. 1994. Systematic Theology. Leicester: England.

Hanna, A. J. 1956. The beginning of Nyasaland and North Eastern Rhodesia 1851-1895, Clarendon Press: Oxford.

Hayden, D 2009. Kénōsis in Action: Message. Cincinnati Friends meeting, Cincinnati: Ohio, (20/9/09) 
Examining the KENOSIS of the CCAP of Blantyre Synod in poverty alleviation in Malawi

Kalinga, O. 1998. The production of history in Malawi in the 1960's: The legacy of Sir Harry Johnston, the influence of the society of Malawi and the role of Dr.Kamuzu Banda and his Malawi Congress Party. African Affair, 97 (389), pp. 523-549.

Laws, R.,1934. Reminiscences of Livingstonia. Oliver and Boyd : Edinburgh.

Mangisa, L. Interviews: Blantyre Synod Headquarters: Blantyre $(25 / 2 / 07)$.

McClain, J. A., 1967. Doctrine of the kenōsis in Phillippians 2:5-8. Grace Journal, 8(2). 3-13.

Mokiwa. Oral interview: Alice-Univerity of Fort Hare for CCAP Blantyre Synod. (19/5/11).

Pachai, B. 1972 (ed). Early history of Malawi, Longman: London

Phiri, D. 2004. History of Malawi: From earliest times to the year 1915, Claim: Blantyre

Ravenhill, $L$ (ed) 1961. A treasury of prayer: from the writings of $E$. $M$. Bounds. Ravenhill Press: Greensburg, La.

Richard, L 1982. A Kénōtic Christology: in the humanity of Jesus Christ, the compassion of our God. University press of America: Lanham, NY.

Ross, A.C. 1996. Blantyre Mission and the making of modern Malawi. Assemblies of God Press: Blantyre.

Selfridge, J. 1976. The Church's First Thirty Years in Nyasaland (Malawi) 1861-1891. Nkhoma Press: Nkhoma, Lilongwe.

Strong, J 2001. The Strongest Strong's Exhaustive concordance of the bible (larger print edition). Zondervan: Grand Rapids, Michigan.

Twaibu, R.W. 2007. Personal Interview. Head Department, Blantyre Development Commission, Blantyre Synod: Blantyre.

Weller, L. et al 1984. Mainstream Christianity to 1980, Malawi, Zambia, Zimbabwe. Mambo Press: Gwelo.

Williams, D T 2009. Kénōsis of God: the self limitation of God-Father, Son and the Holy Spirit. iUniverse: NY.

Williams, D T 2007. Have this Mind: Following the Examples of Christ. iUniverse: NY. 